\title{
Structural optical and magnetic properties of transition metal doped ZnO magnetic nanoparticles synthesized by sol-gel auto-combustion method
}

\author{
Madiha SARfraZ ${ }^{1}$, NASAR Ahmed ${ }^{2, *}$, KhIZAR-Ul-HaQ $^{1,2}$, Shabnam Shahida $^{3}$, \\ M. A. KHAN ${ }^{4}$ \\ ${ }^{1}$ Department of Physics, Mirpur University of Science and Technology (MUST), Mirpur-10250 (AJK), Pakistan \\ ${ }^{2}$ Department of Physics, University of Azad Jammu and Kashmir Muzaffarabad, AJK 13100, Pakistan \\ ${ }^{3}$ Department of Chemistry, University of the Poonch, Rawalakot, Azad Kashmir, Pakistan \\ ${ }^{4}$ Woman University of Azad Jammu and Kashmir, Bagh, Azad Kashmir
}

\begin{abstract}
Transition metals, such as chromium $(\mathrm{Cr})$ and manganese $(\mathrm{Mn})$ doped zinc oxide $(\mathrm{ZnO})$ magnetic nanoparticles, were synthesized via sole gel auto-combustion method. The prepared magnetic $\left(\mathrm{Zn}_{1-(\mathrm{x}+\mathrm{y})} \mathrm{Mn}_{\mathrm{x}} \mathrm{Cr} \mathrm{y}\right.$, where $\left.\mathrm{x}, \mathrm{y}=0,0.02,0.075\right)$ nanoparticles were calcined in an oven at $6000{ }^{\circ} \mathrm{C}$ for 2 hours. The morphologies of the nanoparticles were investigated using different techniques. X-ray diffraction (XRD) analysis revealed that the hexagonal wurtzite structure of the synthesized nanoparticles was unaffected by doping concentration. The crystallite size measured by Scherrer formula was in the range of $32 \mathrm{~nm}$ to $38 \mathrm{~nm}$ at different doping concentrations. Nanosized particles with well-defined boundaries were observed using a field emission scanning electron microscopy (FE-SEM). Fourier transform infrared (FT-IR) spectra showed a wide absorption band around $1589 \mathrm{~cm}^{-1}$ in all the samples, corresponding to the stretching vibration of zinc and oxygen $\mathrm{Zn}-\mathrm{O}$ bond. A blue shift in optical band gaps from $3.20 \mathrm{eV}$ for $\mathrm{ZnO}$ to $3.08 \mathrm{eV}$ for $\mathrm{Zn}_{0.85} \mathrm{Mn}_{0.075} \mathrm{Cr}_{0.075} \mathrm{O}$ nanoparticles was observed in diffuse reflectance spectra, which was attributed to the sp-d exchange interactions. The field-dependent magnetization M-H loops were measured using vibrating sample magnetometer (VSM). The VSM results revealed diamagnetic behavior of the $\mathrm{ZnO}$ nanoparticles which changed into ferromagnetic, depending on the doping concentration and particle size. The compositions of $\mathrm{Zn}$, $\mathrm{Cr}, \mathrm{Mn}$ and $\mathrm{O}$ in the prepared samples were confirmed by using the energy dispersive X-ray spectroscopy (EDX). Our results provided an interesting route to improve magnetic properties of $\mathrm{ZnO}$ nanoparticles, which may get significant attention for the fabrication of magnetic semiconductors.
\end{abstract}

Keywords: optical band gap; auto-combustion method; room-temperature ferromagnetism; transition-metal doped ZnO nanoparticles; magnetic materials

\section{Introduction}

Synthesis of nanomaterials is important in various fields of fundamental and applied research due to their remarkable physical and chemical properties. Among all nanostructured materials, zinc oxide has gained remarkable attention due to its significant properties such as piezoelectricity and direct wide band gap of about $3.39 \mathrm{eV}$. It has a wide range of applications in electronics, optoelectronics, electrochemical and electromechanical devices, such as ultraviolet lasers, light-emitting

*E-mail: nasar.ahmed@ajku.edu.pk diodes, field emission devices, transistors, high performance nanosensors, solar cells, solar cell windows, piezoelectric nanogenerators, conductive electrodes and nanopiezotronics [1-3]. $\mathrm{ZnO}$ is an important multifunctional semiconductor material also used in solar energy transformation, magnetic storage media, catalysis and optical/electrical switching devices $[4,5]$. $\mathrm{ZnO}$ is widely used because of its low cost, nontoxicity and rich resources in nature. It is also considered as biocompatible and bio-safe element for environmental and medical applications [6]. Among other transition metal oxides such as chromium, iron, cobalt, nickel and copper, transition metal doped $\mathrm{ZnO}$ received 
substantial interest among the researchers due to tunable optical and electrical properties [5, 6]. Transition metal doped $\mathrm{ZnO}$ is utilized for different applications. It has been reported that the properties of $\mathrm{ZnO}$ can be tuned by doping of transition metals [7-12]. Doping of different transition metals (e.g. $\mathrm{Cr}, \mathrm{Mn}, \mathrm{Ni}, \mathrm{Co}, \mathrm{Fe}$ ) in $\mathrm{ZnO}$ can improve its structural, optical, electrical and magnetic properties significantly [9-12]. Transition metal doped$\mathrm{ZnO}$ nanostructures can be fabricated using different techniques, such as organometallic precursor method [7], microemulsion process [8], microwave hydrothermal process [9], sol-gel synthesis [10], precipitation method [11], physical vapor deposition [12], solvothermal synthesis [13], hydrothermal synthesis [13, 14], chemical methods [15] and auto-combustion method [16]. Among all these methods, auto-combustion method yields homogeneous, good quality nanoparticles in a short period of time.

It is well known that pure $\mathrm{ZnO}$ nanoparticles have diamagnetic properties, which has also been observed in our results. However, the $\mathrm{Cr}-\mathrm{Mn}$-doped $\mathrm{ZnO}$ nanoparticles show improved magnetic and optical properties. As the ionic radii of chromium and zinc are comparable to zinc, therefore these ions can easily substitute into the $\mathrm{ZnO}$ crystal. Moreover, the doping of $\mathrm{Cr}$ and $\mathrm{Mn}$ into the $\mathrm{ZnO}$ nanoparticles can improve their physical, optical and magnetic properties without disturbing the $\mathrm{ZnO}$ crystal structure. Due to these substantial properties, $\mathrm{Cr}$ and $\mathrm{Mn}$ doped $\mathrm{ZnO}$ nanoparticles have a variety of applications. For example, transition metal $(\mathrm{Cr})$ doped $\mathrm{ZnO}$ nanoparticles are considered as low-cost adsorbent with high adsorption capacities [17]. Among all diluted magnetic oxides, $\mathrm{Mn}$-doped $\mathrm{ZnO}$ is easier to fabricate and is widely used in the optoelectronic devices as it shows room temperature ferromagnetism [18]. Zhong et. al. [19] reported the enhancement in $\mathrm{Zn}$ vacancies at room temperature in $\mathrm{Cr}-\mathrm{Mn}$ doped $\mathrm{ZnO}$ nanorods obtained by hydrothermal method.

In this contribution, auto-combustion method is utilized for synthesis of $\mathrm{Cr}-\mathrm{Mn}$ doped $\mathrm{ZnO}$ nanoparticles due to its simplicity, less time consumption and cost effectiveness. The effect of doping (Cr, Mn) on optical, structural and magnetic properties has been investigated. It is demonstrated that by increasing the doping concentration of transition metals $(\mathrm{Cr}-\mathrm{Mn})$, $\mathrm{ZnO}$ nanoparticles turn the behavior from diato paramagnetism. It is also demonstrated that auto-combustion method is an effective method to get high-quality magnetic materials in very short period of time.

\section{Experimental}

\subsection{Fabrication of $\mathrm{ZnO}$ nanoparticles}

Pure $\mathrm{ZnO}$ nanoparticles were synthesized using auto-combustion method. Appropriate amounts of zinc nitrate $\mathrm{Zn}\left(\mathrm{NO}_{3}\right)_{2} \cdot 6 \mathrm{H}_{2} \mathrm{O}$ and glycine were mixed in $100 \mathrm{~mL}$ distilled water. The whole system was transferred on a hot plate (Robus Technology RT-550) at $300{ }^{\circ} \mathrm{C}$ under constant stirring (fixed at $550 \mathrm{rpm}$ ). After 1 and half hour, the solution was converted into gel. After few minutes, combustion was started and large amount of volatile gases, such as $\mathrm{CO}_{2}, \mathrm{~N}_{2}$ evolved during the combustion and offwhite color powder of $\mathrm{ZnO}$ was obtained. Then the dry sample was further grinded in an agate mortar to get fine particles.

\subsection{Fabrication of $\mathrm{Cr}-\mathrm{Mn}$ doped $\mathrm{ZnO}$ nanoparticles}

$\mathrm{Cr}$ and $\mathrm{Mn}$ doped $\mathrm{ZnO}$ nanoparticles were prepared by taking suitable amounts of zinc nitrate $\mathrm{Zn}\left(\mathrm{NO}_{3}\right)_{2} \cdot 6 \mathrm{H}_{2} \mathrm{O}$, glycine, chromium nitrate $\mathrm{Cr}\left(\mathrm{NO}_{3}\right)_{2} \cdot 6 \mathrm{H}_{2} \mathrm{O}$ and manganese nitrate $\mathrm{Mn}$ $\left(\mathrm{NO}_{3}\right)_{2} \cdot 4 \mathrm{H}_{2} \mathrm{O}$ measured by a highly sensitive electronic balance (AFD AK-300H). This electronic balance can be used for weighing substances to the milligram $(0.001 \mathrm{~g})$ level. The $\mathrm{Zn}\left(\mathrm{NO}_{3}\right)_{2} \cdot 6 \mathrm{H}_{2} \mathrm{O}$, glycine, $\mathrm{Cr}\left(\mathrm{NO}_{3}\right)_{2} \cdot 6 \mathrm{H}_{2} \mathrm{O}$ and $\mathrm{Mn}\left(\mathrm{NO}_{3}\right)_{2} \cdot 4 \mathrm{H}_{2} \mathrm{O}$ were mixed in $100 \mathrm{~mL}$ distilled water until the color of solution become alpine. The mixed solution was placed on a hot plate at $300{ }^{\circ} \mathrm{C}$ under constant stirring until the color of the solution was changed into violet. With passage of time, the solution was converted into a gel and the color of the solution was changed into dark green. After one and half hour the combustion was started and large amount of gases such as $\mathrm{CO}_{2}, \mathrm{~N}_{2}$ evolved and 
a fine powder was collected. The powder was further grinded in an agate mortar until fine $\mathrm{Cr}$ and $\mathrm{Mn}$ co-doped $\mathrm{ZnO}$ nanoparticles were obtained. All the samples were calcined in a muffle furnace at $600{ }^{\circ} \mathrm{C}$ for 2 hours to remove the volatile gases from the samples. Flow chart of the experimental procedure is given in Fig. 1.

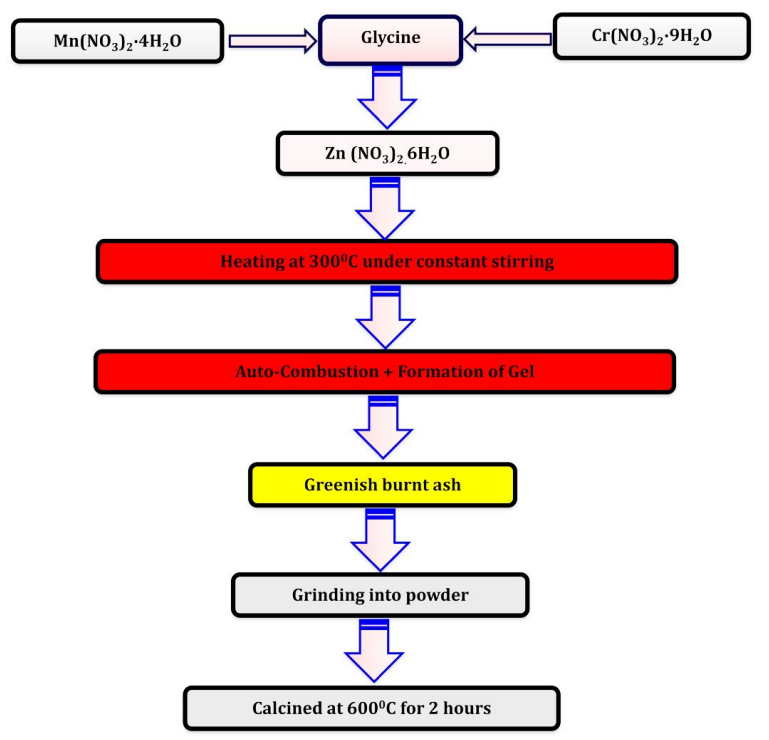

Fig. 1. Flow chart for the synthesis of $\mathrm{Zn}_{1-(\mathrm{x}+\mathrm{y})} \mathrm{Mn}_{\mathrm{x}} \mathrm{Cr}_{\mathrm{y}} \mathrm{O}$ nanoparticles.

\section{Characterization techniques}

Three samples of transition metal doped magnetic semiconductor $\mathrm{Zn}_{1-(\mathrm{x}+\mathrm{y})} \mathrm{Mn}_{\mathrm{x}} \mathrm{Cr}_{\mathrm{y}} \mathrm{O}$ were prepared using auto-combustion with the varying dopant concentrations. Sample S-I was composed of pure $\mathrm{ZnO}$ nanoparticles with zero dopant concentration whereas, sample $\mathrm{S}$-II and S-III were composed of $\mathrm{Zn}_{0.96} \mathrm{Mn}_{0.02} \mathrm{Cr}_{0.02} \mathrm{O}$ and $\mathrm{Zn}_{0.85} \mathrm{Mn}_{0.075} \mathrm{Cr}_{0.075} \mathrm{O}$, respectively.

The surface morphologies and elemental compositions of the nanoparticles were investigated by a field emission scanning electron microscope (FE-SEM) and energy dispersive X-ray spectrometer (EDX). The crystal structure of the prepared samples was analyzed by a X-ray diffraction (XRD Bruker B8 Advance) with $\mathrm{CuK} \alpha$ radiation $(\lambda=1.54 \AA)$ in the range of $2 \theta=20^{\circ}$ to $80^{\circ}$. Fourier transform infrared spectroscopy (FT-IR) was used to identify the functional groups of the molecules or types of chemical bonds in the range of $500 \mathrm{~cm}^{-1}$ to $4000 \mathrm{~cm}^{-1}$. The optical analysis was carried out with the help of PerkinElmer UV-Vis-NIR spectrometer in the reflectance mode in the range of $350 \mathrm{~nm}$ to $650 \mathrm{~nm}$ and vibrating sample magnetometer (Lake Shore, Model 7407) operated under the applied field $10 \mathrm{kOe}$ was used to study the magnetic properties of the samples.

\section{Results and discussion}

\subsection{Structural analysis}

The structural analyses of pure $\mathrm{ZnO}$, $\mathrm{Zn}_{0.96} \mathrm{Mn}_{0.02} \mathrm{Cr}_{0.02} \mathrm{O}$ and $\mathrm{Zn}_{0.85} \mathrm{Mn}_{0.075} \mathrm{Cr}_{0.075} \mathrm{O}$ nanoparticles calcined at $600{ }^{\circ} \mathrm{C}$ were carried out using X-ray diffractometer (XRD). The XRD results are shown in Fig. 2. The diffraction peaks observed around $31.9^{\circ}, 34.2^{\circ}, 36.1^{\circ}, 46.7^{\circ}, 56.3^{\circ}$, $62.5^{\circ}, 66.2^{\circ}, 69^{\circ}$ and $70.5^{\circ}$ are assigned to $\left(\begin{array}{lll}1 & 0 & 0\end{array}\right)$, (l $\left.\begin{array}{lll}0 & 2\end{array}\right),\left(\begin{array}{lll}1 & 0 & 1\end{array}\right),\left(\begin{array}{lll}1 & 0 & 2\end{array}\right),\left(\begin{array}{lll}1 & 1 & 0\end{array}\right),\left(\begin{array}{lll}1 & 0 & 3\end{array}\right),\left(\begin{array}{lll}2 & 0 & 0\end{array}\right)$, $\left(\begin{array}{lll}1 & 1 & 2\end{array}\right)$ and (2 01 l $)$ planes, respectively [20, 21]. These diffraction peaks are the fingerprint peaks of $\mathrm{ZnO}$. All the detected peaks correspond to wurtzite structure of $\mathrm{ZnO}$ matched with JCPDS file for $\mathrm{ZnO}$ (JCPDS Card No. 00-001-1136). The sharpness and height of the diffraction peaks proves the high crystalline nature of the fabricated nanoparticles.

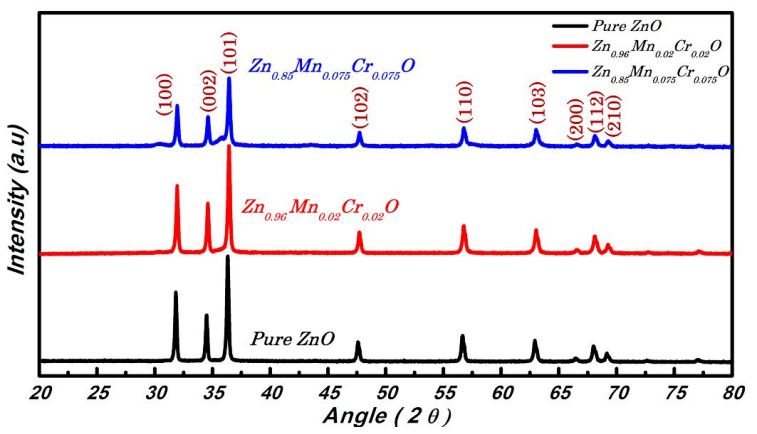

Fig. 2. X-ray diffraction patterns of $\mathrm{Zn}_{1-(\mathrm{x}+\mathrm{y})} \mathrm{Mn}_{\mathrm{x}} \mathrm{Cr}_{\mathrm{y}} \mathrm{O}$.

The phase shift analyses for $\left(\begin{array}{lll}1 & 0 & 1\end{array}\right)$ peak in the XRD patterns are shown in Fig. 3. Such shifting of the XRD peaks reveals a lattice contraction because the ionic radii of $\mathrm{Cr}^{3+}(0.63 \AA)$ and $\mathrm{Mn}^{2+}(0.67 \AA)$ 
are less than that of $\mathrm{Zn}^{2+}(0.74 \AA)$ [19, 21]. Additionally, for the $\mathrm{ZnO}, \mathrm{Zn}_{0.96} \mathrm{Mn}_{0.02} \mathrm{Cr}_{0.02} \mathrm{O}$ and $\mathrm{Zn}_{0.85} \mathrm{Mn}_{0.075} \mathrm{Cr}_{0.075} \mathrm{O}$ nanoparticles, the peaks slightly shift towards higher angle with the increase in doping concentration as shown in the Fig. 3. The shift in the diffraction peaks is attributed to the decrease in the crystallite size with dopant concentration and less ionic radii of $\mathrm{Cr}$ and $\mathrm{Mn}$ atoms as compared to $\mathrm{Zn}(\mathrm{R}=0.74 \AA)$. The doping of $\mathrm{Cr}$ and $\mathrm{Mn}$ in $\mathrm{ZnO}$ results in replacement of $\mathrm{Zn}$ with $\mathrm{Cr}$ or $\mathrm{Mn}$. Hence, the tensile stresses in the $\mathrm{ZnO}$ are produced which results in the positive shift of the $\mathrm{ZnO}$ peak. The positive shift indicates that when transition metals are introduced into $\mathrm{ZnO}$ matrix, the lattice contracts and the lattice parameter decreases. Thus, the positive peak shift with increasing concentration of transition metals is an indication of their presence at the $\mathrm{Zn}$ sites [21].

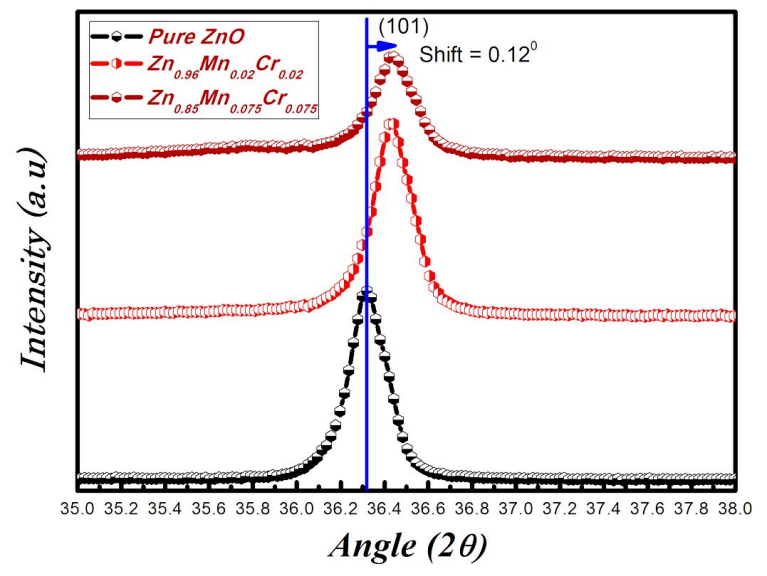

Fig. 3. Shift analysis for $\left(\begin{array}{lll}1 & 0 & 1\end{array}\right)$ peak of $\mathrm{Zn}_{1-(\mathrm{x}+\mathrm{y})} \mathrm{Mn}_{\mathrm{x}} \mathrm{Cr}_{\mathrm{y}} \mathrm{O}$.

The average crystallite size was determined using Scherrer formula [21] as:

$$
D=\frac{0.9 \lambda}{\beta \cos \theta}
$$

where $\lambda$ is the wavelength of the $\mathrm{X}$-ray, $\beta$ is full width at half maximum (FWHM) of diffraction peak and $\theta$ is diffraction angle. It is observed that the FWHM of the fingerprint diffraction peak of $\mathrm{ZnO}\left(\begin{array}{lll}1 & 0 & 1\end{array}\right)$ increases with the increase in the concentration of $\mathrm{Mn}$ and $\mathrm{Cr}$; consequently, the size of nanoparticles decreases with the increase in the concentration as given in Table 1. The decrease in the crystallite size is attributed to the decrease in nucleation of $\mathrm{ZnO}$ nanoparticles with the increase in the doping concentration.

Table 1. Crystallite size of $\mathrm{ZnO}, \mathrm{Zn}_{0.96} \mathrm{Mn}_{0.02} \mathrm{Cr}_{0.02} \mathrm{O}$ and $\mathrm{Zn}_{0.85} \mathrm{Mn}_{0.075} \mathrm{Cr}_{0.075} \mathrm{O}$ estimated using $\mathrm{ZnO}\left(\begin{array}{lll}1 & 0 & 1\end{array}\right)$ diffraction peak

\begin{tabular}{lc}
\hline \multicolumn{1}{c}{ Sample } & Crystallite size [nm] \\
\hline \hline Pure $\mathrm{ZnO}$ & 38.43 \\
$\mathrm{Zn}_{0.96} \mathrm{Mn}_{0.02} \mathrm{Cr}_{0.02} \mathrm{O}$ & 36.52 \\
$\mathrm{Zn}_{0.85} \mathrm{Mn}_{0.075} \mathrm{Cr}_{0.075} \mathrm{O}$ & 32.46 \\
\hline
\end{tabular}

\subsection{Lattice parameters}

The lattice parameters a and $\mathrm{c}$ of the samples were calculated by using equation 2 :

$$
\frac{1}{d^{2}}=\frac{4}{3} \frac{\left[h^{2}+h k+k^{2}\right]}{a^{2}}+\frac{l^{2}}{c^{2}}
$$

where $\mathrm{d}$ is the interplanar spacing, $\mathrm{h}, \mathrm{k}$ and 1 are the Miller indices. By making the use of the Bragg law:

$$
2 d \sin \theta=n \lambda
$$

the lattice parameter a is calculated for $\left(\begin{array}{lll}1 & 0 & 0\end{array}\right)$ plane using following equation 4 :

$$
a=\frac{\lambda}{\sqrt{3} \sin \theta}
$$

For the plane $\left(\begin{array}{lll}0 & 0 & 2\end{array}\right)$ the lattice parameter $c$ is calculated using following equation 5 :

$$
c=\frac{\lambda}{\sin \theta}
$$

The calculated lattice parameters for pure and doped $\mathrm{ZnO}$ nanoparticles are in excellent agreement to the reported values (JCPDS Card No. 00-001-1136) as given in Table 2. 


\subsection{Volume of unit cell}

The volume of unit cell is calculated using equation 6 [21] as:

$$
V=\frac{\sqrt{3}}{2} a^{2} c
$$

Again, the volume of the calculated doped $\mathrm{ZnO}$ nanoparticles was found to be very close to the reported volume (JCPDS Card No. 00-001-1136).

\subsection{Bond length}

The bond length of $\mathrm{ZnO}$ and $\mathrm{Cr}$ and $\mathrm{Mn}$ doped $\mathrm{ZnO}$ was calculated using following relation [22]:

$$
L=\sqrt{\frac{a^{2}}{3}+\left(\frac{1}{2}-u\right)^{2} c^{2}}
$$

where $\mathrm{u}$ is the positional parameter in the wurtzite structure and is a measure of amount by which each atom is displaced with respect to the next along $\mathrm{c}$ axis. The value of $\mathrm{u}$ can be calculated using equation 8 :

$$
u=\frac{a^{2}}{3 c^{2}}+0.25
$$

The values of lattice parameters $(a, c), c / a$, unit cell volume and bond length are listed in the Table 2. It is observed that the unit cell volume and lattice parameters slightly decreased with the increase in the dopant concentration whereas, the bond length slightly increased with the increase in lattice parameters a and $\mathrm{c}$. This slight variation in the lattice parameters of $\mathrm{Zn}_{0.96} \mathrm{Mn}_{0.02} \mathrm{Cr}_{0.02} \mathrm{O}$ and $\mathrm{Zn}_{0.85} \mathrm{Mn}_{0.075} \mathrm{Cr}_{0.075} \mathrm{O}$ is due to the substitution of $\mathrm{Cr}$ and $\mathrm{Mn}$ ions with different ionic radii. The slight variation in the aspect ratio (c/a) suggests that the dopant ions are well incorporated into the $\mathrm{ZnO}$ crystal lattice.

\section{Morphology and compositional analysis}

The structural morphology and shape of the nanoparticles was studied by FE-SEM. In Fig. 4a and Fig. 4b we present the FE-SEM images of $\mathrm{Cr}-\mathrm{Mn}$ doped $\mathrm{ZnO}\left(\mathrm{Zn}_{0.96} \mathrm{Mn}_{0.02} \mathrm{Cr}_{0.02} \mathrm{O}\right.$ and $\mathrm{Zn}_{0.85} \mathrm{Mn}_{0.075} \mathrm{Cr}_{0.075} \mathrm{O}$ ) nanoparticles. The particle agglomeration is observed in both of the samples. SEM images show spherical shaped well defined particles. Average grain size was calculated about $30 \mathrm{~nm}$ to $38 \mathrm{~nm}$ using Image $\mathbf{J}$ software which validates our XRD results.
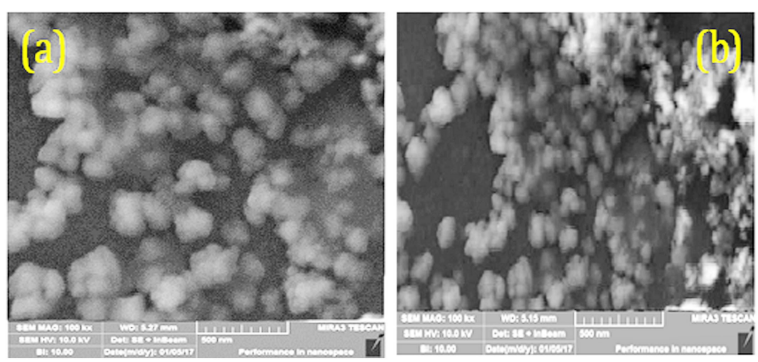

Fig. 4. FE-SEM image of $\mathrm{Zn}_{0.96} \mathrm{Mn}_{0.02} \mathrm{Cr}_{0.02} \mathrm{O}$ (a) and $\mathrm{Zn}_{0.85} \mathrm{Mn}_{0.075} \mathrm{Cr}_{0.075} \mathrm{O}$ (b) nanoparticles calcined at $600{ }^{\circ} \mathrm{C}$.

The elemental compositional analyses of $\mathrm{Zn}_{0.96} \mathrm{Mn}_{0.02} \mathrm{Cr}_{0.02} \mathrm{O}$ and $\mathrm{Zn}_{0.85} \mathrm{Mn}_{0.075} \mathrm{Cr}_{0.075} \mathrm{O}$ nanoparticles were carried out using the EDX attached to the SEM. The results of EDS confirmed the presence of $\mathrm{Zn}, \mathrm{Cr}, \mathrm{Mn}$, and $\mathrm{O}$ as the major elements in these samples, as shown in Fig. 5a and Fig. 5b. The peaks around $0.53 \mathrm{keV}$, $1.03 \mathrm{keV}, 8.64 \mathrm{keV}$ and $9.58 \mathrm{keV}$ belong to $\mathrm{O}$ and $\mathrm{Zn}$, whereas, the peaks near $0.5 \mathrm{keV}$ and $6 \mathrm{keV}$ belong to $\mathrm{Mn}$ and the peaks at $0.55 \mathrm{keV}$, $5.5 \mathrm{keV}$ and $6 \mathrm{keV}$ belong to $\mathrm{Cr}$. The weight and atomic percentage (wt.\%) of the $\mathrm{Zn}, \mathrm{Cr}, \mathrm{Mn}$, and $\mathrm{O}$ obtained from EDS are inserted in Fig. 3 as an inset. The decrease in the oxygen content with the increasing $\mathrm{Cr}$ and $\mathrm{Mn}$ doping confirms the substitution of $\mathrm{Cr}$ and $\mathrm{Mn}$ into $\mathrm{ZnO}$.

\section{FT-IR spectroscopy}

In Fig. 6 we present the FT-IR spectra of pure and $\mathrm{Cr}-\mathrm{Mn}$ doped $\mathrm{ZnO}$ nanoparticles in the wave number range $500 \mathrm{~cm}^{-1}$ to $4000 \mathrm{~cm}^{-1}$ in black, green and blue color. The peak height and band position of the FT-IR spectra depend on the crystal structure and chemical composition of prepared nanoparticles. From Fig. 6 it is clear that strong absorption peak around $1589 \mathrm{~cm}^{-1}$ is due to $\mathrm{Zn}-\mathrm{O}$ stretching mode. The peaks near 
Table 2. The lattice parameters, volume of unit cell and bond length of $\mathrm{Zn}_{1-(\mathrm{x}+\mathrm{y})} \mathrm{Mn}_{\mathrm{x}} \mathrm{Cr}_{\mathrm{y}} \mathrm{O}$

\begin{tabular}{lcrrcc}
\hline \multicolumn{1}{c}{ Samples } & \multicolumn{2}{c}{$\begin{array}{c}\text { Lattice parameters } \\
\mathrm{a}[\AA] \mathrm{c}[\AA]\end{array}$} & $\mathrm{c} / \mathrm{a}$ & $\begin{array}{c}\text { Unit cell } \\
\text { volume }\end{array}$ & $\begin{array}{c}\text { Bond length } \\
{[\AA]}\end{array}$ \\
\hline \hline Pure $\mathrm{ZnO}$ & 3.2472 & 5.1993 & 1.6012 & 47.48 & 1.9759 \\
$\mathrm{Zn}_{0.96} \mathrm{Mn}_{0.02} \mathrm{Cr}_{0.02} \mathrm{O}$ & 3.2350 & 5.1844 & 1.6026 & 46.99 & 1.9689 \\
$\mathrm{Zn}_{0.85} \mathrm{Mn}_{0.075} \mathrm{Cr}_{0.075} \mathrm{O}$ & 3.2350 & 5.1814 & 1.6017 & 46.96 & 1.9687 \\
\hline
\end{tabular}
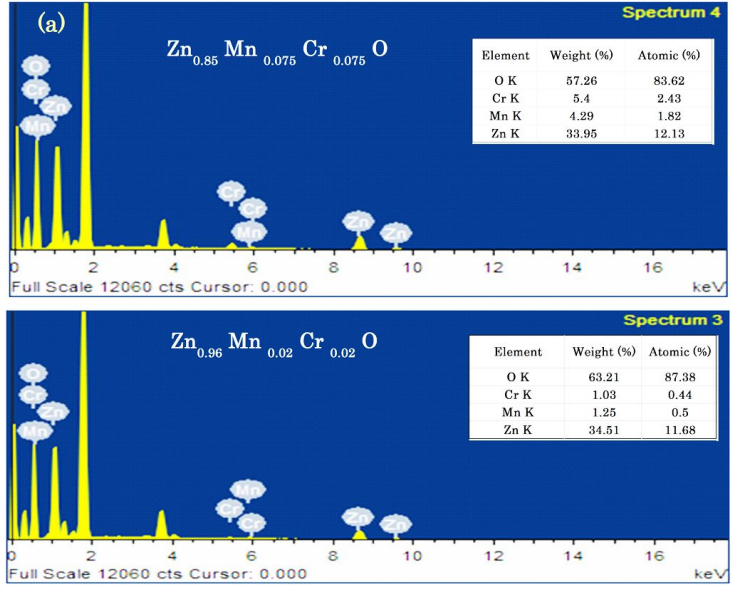

Fig. 5. EDX spectra of $\mathrm{Zn}_{0.96} \mathrm{Mn}_{0.02} \mathrm{Cr}_{0.02} \mathrm{O}$ (a) and $\mathrm{Zn}_{0.85} \mathrm{Mn}_{0.075} \mathrm{Cr}_{0.075} \mathrm{O}$ (b) nanoparticles.

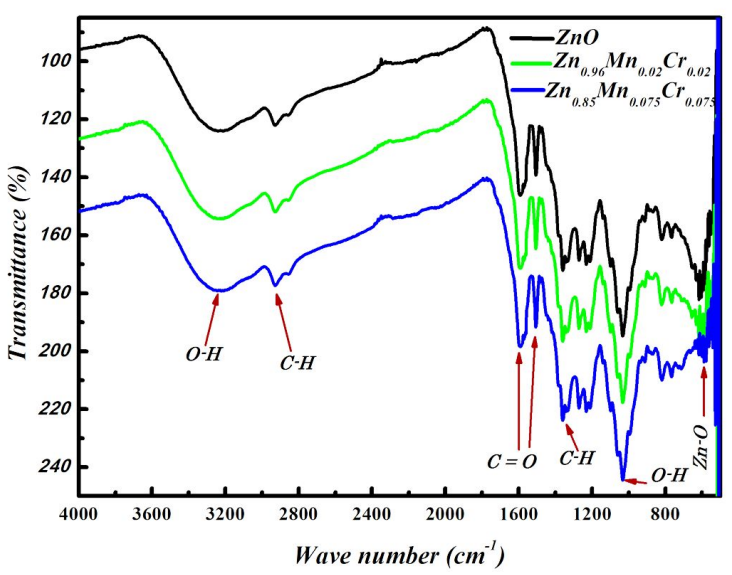

Fig. 6. FT-IR spectra of $\mathrm{Zn}_{1-(\mathrm{x}+\mathrm{y})} \mathrm{Mn}_{\mathrm{x}} \mathrm{Cr}_{\mathrm{y}} \mathrm{O}$ magnetic nanoparticles.

$1029 \mathrm{~cm}^{-1}, 3244 \mathrm{~cm}^{-1}$ and $3237 \mathrm{~cm}^{-1}$ belong to $\mathrm{O}-\mathrm{H}$ stretching vibrations. The peak at wave number $1590 \mathrm{~cm}^{-1}$ corresponds to the bending of $\mathrm{N}-\mathrm{H}$ and at $1035 \mathrm{~cm}^{-1}$ corresponds to the $\mathrm{C}-\mathrm{N}$ bond vibrations. The peak around $2900 \mathrm{~cm}^{-1}$ is recognized as $\mathrm{C}-\mathrm{H}$ stretching. The sharp peaks

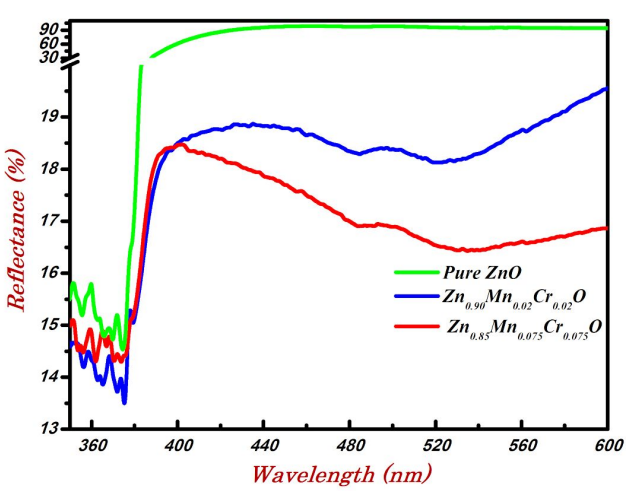

Fig. 7. Diffuse-reflectance spectra of $\mathrm{Zn}_{1-x} \mathrm{Mn}_{\mathrm{x}} \mathrm{Cr}_{\mathrm{y}} \mathrm{O}$ magnetic nanoparticles.

in the range of $1550 \mathrm{~cm}^{-1}$ and $1364 \mathrm{~cm}^{-1}$ belong to symmetric and asymmetric stretching modes of $\mathrm{C}-\mathrm{H}$ [23-25]. As there was not observed any shift in the $\mathrm{Zn}-\mathrm{O}$ absorption band of the FT-IR spectra therefore all bonds stretching is almost independent of dopant concentration. Thus, it confirms that $\mathrm{Cr}$ and $\mathrm{Mn}$ are incorporated into the $\mathrm{ZnO}$ crystal lattice perfectly $[25,26]$.

\section{Optical characterization}

The optical analysis of $\mathrm{ZnO}$, $\mathrm{Zn}_{0.96} \mathrm{Mn}_{0.02} \mathrm{Cr}_{0.02} \mathrm{O}$ and $\mathrm{Zn}_{0.85} \mathrm{Mn}_{0.075} \mathrm{Cr}_{0.075} \mathrm{O}$ was carried out with the help of PerkinElmer UV-Vis-NIR spectrometer in the range of $350 \mathrm{~nm}$ to $650 \mathrm{~nm}$ in reflectance mode. The results presented in Fig. 7 reveal an absorption peak around $380 \mathrm{~nm}$, attributed to large exciton binding energy and good optical quality of prepared nanoparticles.

The band gap energy for pure and $\mathrm{Cr}-\mathrm{Mn}$ doped $\mathrm{ZnO}$ samples was calculated using the KubelkaMunk function expressed by equation 9 :

$$
F(R)=\frac{(1-R)^{2}}{2 R}
$$


Table 3. Bandgap energies of $\mathrm{Zn}_{1-(\mathrm{x}+\mathrm{y})} \mathrm{Mn}_{\mathrm{x}} \mathrm{Cr}_{\mathrm{y}} \mathrm{O}$

\begin{tabular}{lc}
\hline \multicolumn{1}{c}{ Samples } & Band gap [eV] \\
\hline \hline $\mathrm{ZnO}$ & 3.20 \\
$\mathrm{Zn}_{0.96} \mathrm{Mn}_{0.02} \mathrm{Cr}_{0.02} \mathrm{O}$ & 3.13 \\
$\mathrm{Zn}_{0.85} \mathrm{Mn}_{0.075} \mathrm{Cr}_{0.075} \mathrm{O}$ & 3.08 \\
\hline
\end{tabular}

Here, $\mathrm{R}$ is the reflectance. The graph was plotted between $(\mathrm{F}(\mathrm{R}) \mathrm{hv})^{2}$ versus hv and energy band gap was calculated by extrapolation the linear part of the $(\mathrm{F}(\mathrm{R}) \mathrm{hv})^{2}$ plot to the intersection with hv axis as shown in Fig. 8. It is observed that the bandgap decreases from $3.20 \mathrm{eV}$ [27] to $3.08 \mathrm{eV}$ by increasing the dopant concentration and such behavior has already been observed by many authors in transition metal doped semiconductors [27, 28]. The decrease in band gap with increasing dopant concentration is mainly due to the exchange interaction between $d$ electrons of dopant and $s$ and $p$ electrons of the host which give rise to the negative and positive correction to the conduction and valence band edges resulting in band gap narrowing [28]. It can be explained theoretically by second order perturbation theory.

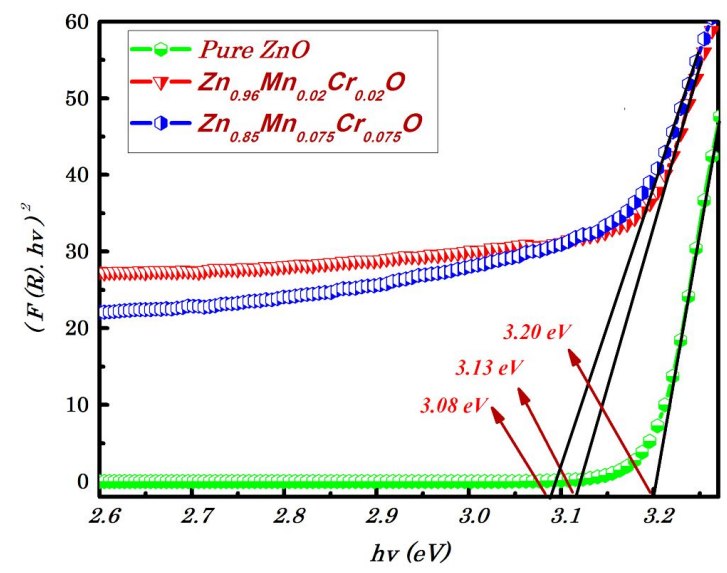

Fig. 8. Band gap measurement of $\mathrm{Zn}_{1-\mathrm{x}} \mathrm{Mn}_{\mathrm{x}} \mathrm{Cr}_{\mathrm{y}} \mathrm{O}$ using Tauc law.

The band gap values of $\mathrm{ZnO}$ and $\mathrm{Mn}, \mathrm{Cr}$ codoped $\mathrm{ZnO}$ for the same and different dopant concentrations are listed in Table 3.

\section{Magnetic calculations}

The magnetic behavior of the synthesized $\mathrm{Zn}_{0.96} \mathrm{Mn}_{0.02} \mathrm{Cr}_{0.02} \mathrm{O}$ and $\mathrm{Zn}_{0.85} \mathrm{Mn}_{0.075} \mathrm{Cr}_{0.075} \mathrm{O}$ particles was measured at room temperature using magnetic field in the range of $-10 \mathrm{kOe}$ to $+10 \mathrm{kOe}$ as shown in Fig. 9a and Fig. 9b. As $\mathrm{ZnO}$ is a diamagnetic type compound, the M-H curve for doped $\mathrm{Zn}_{0.96} \mathrm{Mn}_{0.02} \mathrm{Cr}_{0.02} \mathrm{O}$ shows a negative moment and diamagnetic behavior at room temperature while $\mathrm{Zn}_{0.96} \mathrm{Mn}_{0.02} \mathrm{Cr}_{0.02} \mathrm{O}$ sample shows a paramagnetic behavior at room temperature. The increased concentration of $\mathrm{Cr}$ and $\mathrm{Mn}$ caused the transition from dia- to paramagnetic behavior in the magnetization curve as shown in Fig. 9b. The magnetization of $\mathrm{Zn}_{0.96} \mathrm{Mn}_{0.02} \mathrm{Cr}_{0.02} \mathrm{O}$ sample is stronger than that of the pure $\mathrm{ZnO}$. The value of magnetization for $\mathrm{Zn}_{0.96} \mathrm{Mn}_{0.02} \mathrm{Cr}_{0.02} \mathrm{O}$ is $0.1 \mathrm{emu} / \mathrm{g}$, whereas, for $\mathrm{Zn}_{0.85} \mathrm{Mn}_{0.075} \mathrm{Cr}_{0.075} \mathrm{O}$, M-H curve shows the ferromagnetic behavior with the magnetization greater than $1 \mathrm{emu} / \mathrm{g}$. The magnetic properties of transition metal doped $\mathrm{ZnO}$ nanoparticles depend on the concentration and distribution of the ions, particle size and morphology. It is also noticed that the particle size plays an important role in magnetic behavior of magnetic semiconductors. Magnetization increases with decreasing particle size. As particle size decreases the surface to volume ratio increases and, as a result, the contribution of surface spins to the total magnetic moment of particle increases [29, 30].

\section{Conclusions}

In this study, pure $\mathrm{ZnO}$ and $\mathrm{Cr}-\mathrm{Mn}$ doped $\mathrm{ZnO}$ nanoparticles were successfully synthesized using sol gel auto-combustion method. The XRD result confirmed the hexagonal wurtzite structure of all the prepared nanoparticles. The lattice parameters decreased with the increase in the doping concentration of $\mathrm{Cr}$ and $\mathrm{Mn}$. It was also perceived that XRD peaks shifted to higher diffraction angles because the ionic radii of $\mathrm{Cr}^{3+}(0.63 \AA)$ and $\mathrm{Mn}^{2+}$ $(0.67 \AA)$ are less than that of $\mathrm{Zn}^{2+}(0.74 \AA)$. SEM results confirmed that spherical shaped nanoparticles with the average crystallite size about $32 \mathrm{~nm}$ to $38 \mathrm{~nm}$ were prepared. The particle size 

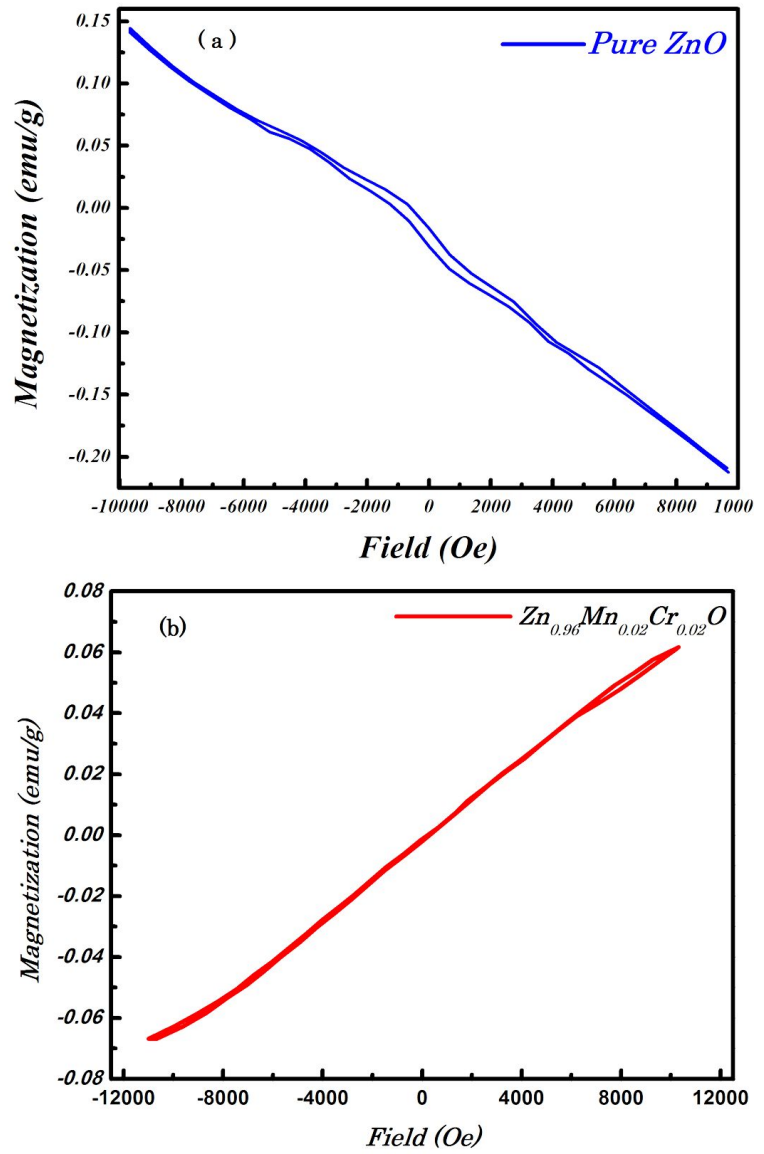

Fig. 9. M-H curve of the $\mathrm{Zn}_{0.96} \mathrm{Mn}_{0.02} \mathrm{Cr}_{0.02} \mathrm{O}$ (a) and $\mathrm{Zn}_{0.85} \mathrm{Mn}_{0.075} \mathrm{Cr}_{0.075} \mathrm{O}$ (b) nanoparticles.

decreased from $38.43 \mathrm{~nm}$ to $32.46 \mathrm{~nm}$ due to the increase in the concentration of $\mathrm{Mn}$ and $\mathrm{Cr}$. The optical band gap decreased from $3.20 \mathrm{eV}$ for $\mathrm{ZnO}$ to $3.08 \mathrm{eV}$ for $\mathrm{Zn}_{0.85} \mathrm{Mn}_{0.075} \mathrm{Cr}_{0.075} \mathrm{O}$ which is attributed to s-d and $\mathrm{p}$ interactions. FT-IR spectra confirmed the chemical compositions of the prepared samples. From the field dependent magnetization curves, pure $\mathrm{ZnO}$ showed diamagnetic behavior, whereas, $\mathrm{Zn}_{0.96} \mathrm{Mn}_{0.02} \mathrm{Cr}_{0.02} \mathrm{O}$ and $\mathrm{Zn}_{0.85} \mathrm{Mn}_{0.075} \mathrm{Cr}_{0.075} \mathrm{O}$ showed para- and ferromagnetic behavior. It is clear that the magnetization increases with the increase in the dopant concentration. Additionally, it is concluded that magnetization increases with a decrease in particle size. The structural, optical and magnetic properties are optimized by increasing the doping concentration. This study not only describes the efficient experimental approach for synthesis of novel adsorbent and doped $\mathrm{ZnO}$ nanoparticles but also offers valuable clues for the preparation and property study of other semiconductor adsorbents and doped materials. Based on this study, different transition metals doped $\mathrm{ZnO}$ nanoparticles with excellent magnetic properties can be synthesized for numerous applications using a simple auto-combustion method.

\section{Acknowledgements}

We are grateful to the Mirpur University Science and Technology (MUST) to provide financial assistance during this research work.

\section{References}

[1] J. Lim H., Kang C.K., Kim K.K., PARK L.K., HWANG D.K., PARK S.J., Adv. Mater., 18 (2006), 2720.

[2] J. Furdyna K., J. Appl. Phys., 64 (1988), 29.

[3] Elilarassi R., Chandrasekaran G., Mater. Electron., 24 (2013), 96.

[4] Zhang J., Zhang L., Peng X., Wang X., Appl. Phys, 73 (2001), 773.

[5] Pan S.L., Zeng D.D., Zhang H.L., Li H.L., Appl. Phys. A, 70 (2000), 637.

[6] Chand P., Gaur A., Kumar A., Int. J. Chem., Nuc. Mat. Metall. Eng., 8 (2014), 12.

[7] Chen W., Lu Y.H., Wang M., Kroner L., Fecht H.J., J. Phys. Chem. C, 113 (2009), 1320.

[8] Wang P.Y., GaO Q.H., XU J.Q., Fine Chem., 24 (2007), 436.

[9] Li D., Huang J.F., CAO L.Y., Jia Y.L., YAnG H.B., YAO C.Y., Ceram. Int., 40 (2014), 2647.

[10] Yue H.Y., FeI W.D., Li Z.J., WANG L.D., J. Sol-Gel Sci. Technol., 44 (2007), 259.

[11] Yang Q., Hu W., Ceram. Int., 36 (2010), 989.

[12] Yousefi R., Kamaluddin B., Solid State Sci., 12 (2010), 252.

[13] Tonto P., Mekasu O., Phatanasri S., PavaraJARn V., Praserthdam P., Ceram. Int., 34 (2008), 57.

[14] Wang J., Shi N., QI Y., LIU M., J. Sol-Gel Sci. Technol., 53 (2009), 101.

[15] Li H., Zhang Z., Huang J., LiU R. Wang Q., J. Alloy. Compd., 550 (2013), 526.

[16] Rajendar V., Dayakar T., Chakra C.H., Shilpa R., Venkateswara S.K., Appl. Nanomed. Nanobio., 2 (2015), 21.

[17] Meng A., Xing J., Li Z., Li Q., ACS Appl. Mater. Interface., 7 (2015), 27449.

[18] Moontragoon P., Pinitsoontorn S., ThongBAI P., Microelectron. Eng., 108 (2013), 158.

[19] Zhong M., Li Y., Hu Y., ZhU M., Li W., Jin H., Zнао H., J. Alloy. Compd., 647 (2015), 823. 
[20] Ahmed N., Majid A., Khan M.A., Rashid M., UMAR Z.A., BAIG M.A., Mater. Sci.-Poland, 36 (2018), 3.

[21] Cullity B.D., Elements of X-ray diffraction, AddisonWesley, $2^{\text {nd }}$ edition 1978.

[22] Umar Z.A., Ahmed N., Ahmed R., Arshad Anwar-Ul-Haq M., Hussain M., Baig M.A., Surf. Interface. Anal., 50 (2018), 1.

[23] Kumar H., Rani R., Int. Let. Chem. Phys. Ast., 14 (2013), 26.

[24] RyU S.R., JANG W., YU S.I., LeE B.H., KWON S., SHIN K., Sci. Res., 6 (2016), 181.

[25] Lammertink R.H., Hempenius M.A., VAnCso G.J., Shin K., Rafailovich M.H., Sokolov J., Macromolecules, 34 (2001), 942.
[26] Saleh R., Purbo S., Prakoso A., J. Magn. Magn. Mater., 324 (2012), 665.

[27] Karunakaran C., Vinayagamoorthy P., JayabHARATHI ELECTRICAL J., Mater. Res. Express, 1 (2014), 045019.

[28] Mary J.A., Vijaya J.J., Int. J. ChemTech Res., 7 (2015), 1351.

[29] Park T.J., Papaefthymiou G.C., Viescas A.J., A Moodenbaugh. R., Wong S.S., Nano. Let., 7 (2007), 766.

[30] Zeyada H.M., Youssif M.I., GhamaZ N.A., Aboderbala E.O., Physica B, 506 (2017), 75.

Received 2018-10-01

Accepted 2019-03-13 